of the world around him. This may become more pronounced if our young scientists are unable to tell about their work and ideas in a way that the ordinary man can understand. To remedy this, I can only suggest that our pupils should be encouraged to read more books in good connected prose, like those on history and philosophy, together with some selected works by scientists well known for their prose style, and that they should be encouraged to try to imitate that style.

There is also much to be said for the study of some complete book or paper of outstanding importance, with special reference to the way in which the subject is presented, the evidence is brought forward, and the conclusion reached.

Many school and university teachers will have a short reply to what I have been saying. They will point out that young scientists have already more than enough to learn, and that they have no time to spare for the kind of instruction $I$ have suggested. This, without doubt, is perfectly true at the present time; but the day must soon come when every British university is forced by the accumulation of knowledge to revise its science-teaching and to make radical changes. Those responsible must face the problem of whether teaching or education is to be the first consideration. When this revision comes I hope that it will enable science students to devote some time throughout their education to the history and philosophy of seience, so that they may obtain a good measure of humanistic culture, and will not tend to become cut off from the intellectual interests of their fellow students.

This brings me to another aspect of my subject, the value of the history of science to those who are not science specialists. In the past, a knowledge of the phenomena of Nature was considered quite unnecessary in the education of those who would not become medical men or science specialists. For a long time the part played by the scientific revolution of the seventeenth century in altering the currents of man's thought and in improving his material environment was clear to those who cared to think about it. But it received little attention, and the practical results which followed and which led to great improvements in our health, food, housing, transport and communications were taken as matters of course. To-day, most educated people have suddenly awakened to the fact that the discoveries of science have brought about the most profound change in human affairs that the world has yet seen, at least since the discovery of metals. No longer can young people be brought up in complete ignorance of modern science. But this does not mean that they can or should be taught chemistry and physics to enable them to understand the process of atomic disintegration, or learn physiology and geneties for the explanation of blood transfusion. What I think is needed is a general picture of how man's knowledge of Nature has come about, and what have been the results of this knowledge. In several schools a successful attempt is being made to inform pupils, by teaching the history of science, of the ways in which discoveries have affected men's lives. The historical approach enables the more important contributions to knowledge to be linked into a connected story. At the same time, it enables many inventions and principles to be understood by reference to the way in which they have developed from simple beginnings. Thus the early experiments of Faraday on electromagnetic induction are not difficult to understand, and when these are known the principle of the modern dynamo can be explained. By this mode of study much can be done to show the way in which biological and medical knowledge has altered the lives of the people of the world, and, may I add, to direct attention to the unacknowledged debt of the inhabitants of Asia and Africa to the labours of European and American scientists. This study will also stress the importance in our lives of vaccination and inoculation, the dangers of bacterial and virus infection, and the value of hygiene. In these days when so many people are terrified by reports of atomic weapons, there is in some minds a feeling that the progress of discovery in the world of Nature is to be regretted; scientists are only regarded as the authors of horrible contrivances. How important it is to show the manifold ways in which everyone has benefited from the labours of the investigators of Nature.

\section{INTERNATIONAL PEAT SYMPOSIUM 1954}

$T$

HE first International Peat Symposium was held in Dublin during July 12-17 under the auspices of Bord na Mona-the statutory corporation set up in Ireland to develop the peat resources of that country. It was attended by more than two hundred delegates from nineteen countries, and sixty-nine papers by delegates from thirteen countries were discussed. Nations as far apart as the United States and Malaya were represented; but one large peat producer - the U.S.S.R. - was absent. However, its near neighbour, Finland, was well represented, as were the Scandinavian countries and Austria.

The reason for this widespread interest in peat varies. In Ireland it is its immediate use as a fuel, followed by the reclamation of the bog for agriculture and afforestation. Elsewhere it may be the conservation of native fuel for use in an emergency, or even the employment of evacuees. Whatever the reason, there is no doubt that interest in peat is more intense now than formerly. In the past it was stimulated by war-time conditions, when other fuels were difficult to obtain, and tended to flag in peacetime. At the present time, economic conditions are such that in some regions peat can compete with other fuels on a calorific basis, particularly when modern methods of production and utilization are used. This has led to more research and development, which in their turn have resulted in further improve. ments in methods and still greater incentives to use peat.

The scope of the conference covered a wide field, including the initial survey and classification of resources, the winning and preparation of the raw material, its utilization in all types and sizes of equipment and, finally, land reclamation.

It was noteworthy that at every stage the discussion was dominated by the same characteristic properties of the material, particularly the large weight and volume of raw material required to produce a given quantity of dry peat substance, its variable composition, and, above all, its high moisture content. Their importance was made strikingly apparent during a visit by the delegates to typical peat bogs and power plants to observe various methods of winning and utilizing peat.

This left the general impression of a long-drawnout struggle against natural conditions requiring a 
series of huge machines systematically to traverse many miles of desolate open country and to handle vast quantities of difficult material only to produce in the end a disproportionately small output of useful heat or power. Taking actual figures, it is hoped that by 1960 it will be possible to remove about 90 million tons of material each year from the Irish bogs to generate about one and a half million megawatt-hours of electricity. In comparison with this, Battersea Power Station generates slightly more power from about three-quarters of a million tons of coal per annum.

To estimate peat resources on a national scale is a formidable task in view of the large areas involved (one-third of Finland and one-seventh of Ireland consist of peat bogs), and the need to take into account variations in bog depth and in the quality of peat in different areas and at different depths. Nevertheless, several countries have made comprehensive surveys, the results of which were made available. One interesting suggestion which may reduce the cost and labour involved in future surveys was that surface vegetation can be correlated with the nature of the peat beneath it, and this will enable useful information to be obtained by relatively inexpensive aerial surveys.

Although peat has many uses, for example, as moss litter and for horticultural purposes, its main value is as a fuel, and it was mainly discussed as such. In passing, it is interesting to note that peat is still won by hand and used for household purposes by the same methods as were described by Pliny nineteen centuries ago. On a larger scale, its winning and utilization are extensively mechanized; but the conference made it abundantly clear that even now the methods employed have by no means reached finality. Thus the two power stations already burning peat in Ireland both use it in the form of machinecut sods or turves; but Bord na Mona has now pinned its faith to granular peat won by a completely different method - the milled peat processand it is its present intention to produce one million tons per annum of sod peat, about half of which will be used for domestic and industrial purposes and about half for power production, plus $2 \frac{1}{2}$ million tons of milled peat, most of which will be used for power production.

Since this decision was made, new machinery has been developed which will reduce very considerably the amount of labour required in the preparation of sod peat, and this must materially affect the relative economies of the two processes, although not necessarily to the extent of reversing their former order of merit.

Although mechanically very different, the fundamental difference between the two principal methods of winning peat is in the provision made for partially drying the fuel. An undrained peat bog usually contains about 93 per cent of moisture, that is, more than $13 \mathrm{lb}$. of water per pound of dry peat substance. Part of this moisture can be removed by drainage; but even then the remaining moisture, say 90 per cent, is far too much to be removed by waste heat, and the nature of the peat is such that it cannot be removed by ordinary mechanical means. Recourse is therefore made to air drying, and the basic difference between the two processes lies in the methods used to bring the fuel into contact with the air. In the sod peat process a strip about six feet wide and nine feet deep is cut from the previously drained bog and, after maceration, spread on the field to dry in the form of sods about $12 \mathrm{in.} \mathrm{long} \mathrm{and} 4 \mathrm{in}$. wide. It is then subjected to periodic turning and stacking and is eventually formed into a long pile in which it is stored until required for use. In the milled peat process, a thin layer about half an inch thick is removed in granular form from the top surface of the previously drained bog by means of a toothed roller and is repeatedly brought into contact with air by harrowing and similar means. Both processes depend upon weather conditions, and on the average during the summer months there will be two harvests of sod peat and fifteen to twenty-five of milled peat.

The seasonal nature of peat winning and its dependence on day-to-day weather conditions, combined with the remoteness of peat bogs from towns and their amenities, involve many labour and sociological problems which, though not discussed in detail, were obviously in the minds of the delegates. Some of these problems would be at least partially solved if some continuous method of drying could be evolved which would be independent of weather conditions and yet economic.

Of the many methods which have been tried, osmosis has been found to be possible but not economic, and 'wet carbonizing' followed by pressing, though found wanting in the past, is still the subject of experiment. Another alternative is to use the Madrück process in which peat powder, previously dried down to about 12 per cent moisture, is mixed with wet peat and the mixture subjected to high sustained pressure; the suggestion being that the dried powder provides channels through which the water escapes while the peat is still under pressure. The moisture content of the final product is about 80 per cent, that is, more than half the moisture is removed in the press. Experimental work with the Madrück process using specially designed presses is now being carried out in Britain by the Ministry of Fuel and Power. If this is successful and enables peat winning to proceed continuously throughout the year, it should greatly ease the future economic position with regard to both capital costs and labour.

In the past, when peat was considered only as an alternative to other fuels, it was almost invariably burned in appliances designed primarily for those other fuels and modified as little as possible to burn peat. There is now a greater tendency to develop special apparatus which takes advantage of the favourable properties of peat, such as its high reactivity, and minimizes the effect of adverse properties such as high moisture content and low bulk density. Modern apparatus also takes account of the high volatile content of peat and the high percentage of carbon dioxide in its distillation products.

The two Irish power stations burning sod peat use more or less conventional chain grates with special pre-drying of the fuel by means of hot air ; but the equipment to burn milled peat in the new stations will require further development work. Powdered peat has already been used for large-scale power production in the U.S.S.R.; but apart from this, experience is not available, unless it be assumed that peat can be burned efficiently by methods similar to those already used extensively on the Continent to burn brown coal. With this in mind, three German manufacturers were commissioned to design and construct three different boilers which will be used for gaining experience of burning milled peat in the new Ferbane power station. In these boilers either finely divided fuel will be burned in suspension after being 
dried by hot gasos while passing through a Krämer mill of the type used for brown coal, or, alternatively, the spreader-stoker system will be employed in which the original milled fuel is projected into the boiler furnace in such a manner that the finer particles are burned in suspension and the coarser particles fall on to a form of chain grate where their combustion is completed.

The combustion of peat in small-scale equipment is equally the subject of experiment. Taking domestic heating as an extreme case, more economical methods of burning peat in the open fireplace have been devised ; but Bord na Mona recommends the use of closed stoves of special design, and ultimately completely autornatic mechanical operation. At the other extreme, large heating boilers are said to give good results when fitted with a furnace of Dutch design which consists essentially of a low-velocity crossdraught gas producer delivering gas into a combustion chamber, where it is burned with carefully controlled secondary air. The most promising device, however, would appear to be a modification of the downjet burner to burn broken sod peat in both domestic and small-scale industrial appliances. Its essential feature is that all the air for combustion is directed as a high-velocity jet upon the top surface of the fuel bed and it can be used over an exceptionally wide range of loads, giving a very high output per unit volume and por unit grate area, and complete combustion with very little excess air.

The high moisture content of peat makes its possible use as a gas turbine fuel of special interest, first because the gas supplied to the turbine is necessarily at a low temperature in order to avoid overheating the blades, and secondly a large quantity of exhaust gas is available at a temperature which permits it to be used for drying. In experiments with the open-cycle gas turbine carried out under the xgis of the Ministry of Fuel and Power, the problem of feeding pulverized peat under pressure has been solved by the use of a fluid-bed feed in conjunction with a 'coal pump', and combustion does not appoar to be too difficult. Problems of blade abrasion, corrosion and ash deposition in the turbine are, however, still unsolved, though under active investigation. In the closed-cycle gas turbino these particular difficulties are avoided by using indirect heating and a clean working fluid, but the system involves more elaborate heat exchangers, including a large 'air boiler'. A contract has been given for a $2,000-\mathrm{kW}$. peat-fired closed-cycle set to generate power in the north of Scotland and an experimental $750-\mathrm{kW}$. open-cycle set will be erected on the same site.

Apart from its present uses, more or less in its raw state, serious consideration has been given to peat as a potential source of high-grade manufactured products. It has, for example, been found possible to extract from it a wax which may itself be converted into new plastics. Attention has also been given to the gasification of peat to make either water gas or synthesis gas, and Bord na Mona has examined a number of complete gasification processes as possible starting points for the manufacture of synthetic ammonia for conversion to fertilizers.

Whatever the method by which peat is utilized, the final stage of exploiting peat resources must be the reclamation of the land, and most of the last two sessions of the Conference were devoted to this subject. In them it was evident that the best use which can be made of the land, whether for grass- land, arable land, or forestry, is a complex question, the answer to which depends upon many factors, such as drainage, acidity and existing vegetation. Wuch information is now available on this subject, but active research into its many aspects still continues.

T. F. HURLEY

\section{OBITUARIES}

\section{Prof. T. F. Dreyer}

Thomas Frederick Dreyer passed away suddenly on July 13, while discussing problems concerning Florisbad with his colleagues. For the past few years, in spite of severe set-backs to his failing health, his main interest was in trying to elucidate the many puzzling features which had been uncovered at the now world-famous site where in 1932 he had discovered the remarkable Florisbad human skull. The amazing wealth of archæological and palæontological material from this site had been increased by the 1952 expedition of the National Museum, Bloemfontein, and Prof. Dreyer was working against time in order to give his findings to the scientific world. Unfortunately, his death prevented him completing this research work.

Dreyer was born in the Cape Province on May 7, 1885 , took his M.A. degree in the University of the Cape of Good Hope and the degree of D.Phil. cum maxima lauda at the University of Halle. After periods of study at Naples and in the United States and Australia, he served for a few years as entomological officer in the South African Agricultural Department. In 1912, at the youthful age of twentyseven, he became professor of zoology, and in addition for a short period professor of geology, at the Grey University College (later the University of the Orange Free State), a post which he filled with distinction up to his retirement in 1950 . He had also been responsible for courses in archæology and bacteriology. Ho continued his research work at the National Museum, Bloemfontein, up to the time of his death.

In addition to his brilliant career as professor of zoology in the University of the Orange Free State, he devoted much of his spare time-and money-to investigating, uncovering and describing some remarkable sites, three of which are of extreme scientific importance, namely, the Matjes River Shelter, the Kakamas area of prehistoric Hottentot graves, and Florisbad. These sites have contributed much, archæologically, anthropologically and palæontologically, towards clearing up the prehistory of South Africa. There are very few regions in South Africa which Prof. Dreyer did not investigate, and his remarkable and rich collection was presented to the National Museum, Bloemfontein, where it is now housed in the T. F. Dreyer Hall for Anthropology and Archæology.

'Those who passed through his hands as students or were fortunate enough to be associated with him in his research work bear only the kindest memories of a big soul. A great worker with boundless energy, he infected his associates with his enthusiasm and gave loyalty for loyalty. A doughty fighter, he could hit out hard during constructive arguments; but never allowed varying points of view to cloud his personal contacts.

His interests extended beyond just his work and research. This is amply demonstrated in the variety of positions held during his career, including member 